\title{
The effect of irregular seismic loading on the validity of the simplified liquefaction procedures
}

Efecto de cargas sísmicas irregulares en la validez de los procedimientos de licuefacción simplificados

Fecha de envío: 12 de diciembre 2018 Fecha de aceptación: 15 de abril 2019

\section{Raúl Norambuena ${ }^{1}$, Vasiliki Tsaparli², Stavroula Kontoe ${ }^{3}$, David Taborda ${ }^{3}$ and David Potts ${ }^{3}$}

\begin{abstract}
${ }^{1}$ Arcadis Chile, Antonio Varas 621, Providencia, Región Metropolitana de Santiago, Chile, raul.norambuena@arcadis.com
${ }^{2}$ Ørsted, Renewable Energy and Environment, 5 Howick Place, London SW1P 1WG, United Kingdom, vasts@orsted.co.uk

${ }^{3}$ Department of Civil and Environmental Engineering, Imperial College London, South Kensington Campus, Skempton Building, London SW7 2AZ, United Kingdom, stavroula.kontoe@imperial.ac.uk, d.taborda@imperial.ac.uk, d.potts@imperial.ac.uk
\end{abstract}

Soil liquefaction has been one of the major hazards for civil engineering projects relating to earthquakes. The simplified liquefaction procedure which is used to assess liquefaction susceptibility in practice is still based on semi-empirical methods. These rely on the assumption that irregular seismic motions can be represented fully by an equivalent number of cycles of uniform stress amplitude, which is based on the peak acceleration measured at ground surface. Most methodologies used to calculate the equivalent number of cycles are based on Miner's damage concept developed for the fatigue analysis of metals. Several researchers have questioned the validity of this concept, as soils have a highly non-linear response. The present work investigates numerically the concept of the equivalent uniform amplitude cycles. Effective stressbased non-linear finite element analyses are performed with a modified bounding surface plasticity model that allows to realistically simulate liquefaction, reproducing the cyclic strength of sands accurately. The seismic response of a $15 \mathrm{~m}$ deep uniform level-ground sand deposit is simulated with full hydro-mechanical coupling to establish the benchmark extent of liquefaction zone. In parallel, the analyses are repeated assuming drained conditions to compute the irregular time-histories, which are then converted to an equivalent number of uniform amplitude cycles. The constant amplitude series are then applied in single element simple shear test simulations, with initial conditions those corresponding to the $7 \mathrm{~m}$ depth in the deposit. The results in terms of the predicted triggering of liquefaction are contrasted to the
Licuefacción sísmica ha sido uno de los mayores peligros para proyectos de ingeniería atribuidos a terremotos. Las metodologías comúnmente utilizadas para evaluar licuefacción siguen basándose en métodos semi-empíricos. El procedimiento simplificado para evaluar el potencial de licuefacción asume que los terremotos pueden ser representados por un número equivalente de ciclos uniformes, proporcionales a la aceleración superficial máxima de un registro. Las principales metodologías para calcular el número equivalente de ciclos están basadas en la regla de daño acumulado de Miner, desarrollada para el análisis de fatiga en metales. La aplicabilidad de este concepto en suelos ha sido ampliamente cuestionada, dado que los suelos tienen un comportamiento no lineal. El presente trabajo investiga numéricamente el concepto de ciclos de amplitud uniforme equivalentes. Se efectúan análisis de esfuerzos no lineales en elementos finitos utilizando un modelo constitutivo de plasticidad de superficie límite que permite simular realísticamente licuefacción, reproduciendo precisamente la resistencia cíclica de las arenas. Bajo un análisis hidro-mecánico acoplado, se estudia un depósito de arenas de $15 \mathrm{~m}$ de profundidad sujeto a solicitaciones sísmicas, a fin de establecer una referencia de los alcances de la licuefacción. En paralelo, se desarrollan análisis de respuesta drenados para obtener los registros irregulares de esfuerzo, los cuales son convertidos en registros cíclicos uniformes. Se efectúan simulaciones de ensayos de corte simple no drenado sometidos a los registros uniformes generados. Los resultados de los ensayos de corte simple se comparan 
predictions of the fully coupled benchmark analyses at the corresponding depth to assess the validity of the Seed et al. (1975) methodology, based on Miner's cumulative damage concept.

Keywords: liquefaction, simplified procedure, finite element analyses, equivalent number of cycles, bounding surface plasticity con los modelos en términos de licuefacción y se concluye sobre la validez de la metodología de Seed et al. (1975), basada en el concepto de daño acumulado de Miner.

Palabras clave: licuefacción, metodología simplificada, análisis de elementos finitos, número equivalente de ciclos, plasticidad de superficie límite

\section{Introduction}

Soil liquefaction constitutes one of the major hazards relating to earthquakes for civil engineering projects and since its acknowledgement at the beginning of the XX century (Hazen, 1920), it has been one of the main areas of focus in the field of geotechnical earthquake engineering.

Many procedures have been developed over the years in order to assess the triggering of liquefaction in a sand deposit subjected to seismic loading. Different approaches exist: qualitative procedures, based on identifying ranges of particle size distribution (Tsuchida, 1970) or based on ageing and geomorphology (Youd and Perkins, 1978); semi-empirical procedures that rely on observations of ground surface manifestation of liquefaction and field testing (Seed and Idriss, 1971; Youd et al., 2001; Idriss and Boulanger, 2008); numerical methods using advanced constitutive models which can realistically simulate pore water pressure build up and liquefaction (Papadimitiou and Bouckovalas, 2002; Taborda, 2011).

The semi-empirical procedures, which are based on information gathered from past earthquake events, prevail in practice. These procedures have evolved over the years incorporating different aspects of the dynamic performance of different types of soils and the nature of the seismic events, but all are in line with the original simplified procedure proposed by Seed and Idriss in the early 70's.

One of the key assumptions in the simplified procedure is the representation of the irregular loading patterns of the design earthquake by an equivalent number of uniform stress amplitude cycles $\left(N_{\mathrm{eq}}\right)$. This is captured through the magnitude scaling factors that are used to scale the seismic demand or the cyclic strength of soils for the calculation of the factor of safety against liquefaction. Perhaps the most common procedure to count the equivalent number of cycles is that proposed by Seed and his colleagues (Seed et al., 1975), consisting of applying weighting factors for stress levels of different percentage of the peak magnitude present in the irregular time-history. This method is based on the cumulative damage rule proposed by Miner (1945), originally developed to study low cycle fatigue conditions in metals.

Shen et al. (1978) carried out a series of cyclic undrained triaxial element tests on sand samples of different relative density $\left(D_{\mathrm{r}}\right)$, subjected to different random loading patterns. Through these they concluded that the resistance to liquefaction strongly depends on the loading path and sequence of loading cycles, particularly for the denser samples, suggesting that Miner's cumulative damage rule may not be applicable to soils undergoing large amplitude cycles during which the respose is mainly non-linear elasto-plastic.

Recent laboratory studies on sand's liquefaction resistance (Azeitero et al., 2012; Coehlo et al., 2013) have shown that a similar dependency of the cyclic strength on the loading sequence exists even for loose samples. More recently, these laboratory findings were corroborated by finite element (FE) analyses, which further concluded that the equivalent number of cycles concept could lead to nonconservative results in terms of liquefaction resistance (Tsaparli, 2015).

The present work extends the study of Tsaparli et al. (2015) on the equivalent number of uniform amplitude cycles concept of the Seed et al. (1975) methodology, by investigating numerically, through use of the Imperial 
College Finite Element Program ICFEP (Potts and Zdravkovic, 1999) the response of sand to liquefaction when subjected to three different types of ground motions of very different characteristics. An advanced constitutive model (Taborda et al., 2014), which has been modified to accurately capture the variation of cyclic strength with the level of applied cyclic stresses (Tsaparli, 2017) further increases the robustness of this study in examining the applicability of the Miner's concept in soils.

\section{Numerical procedure for the evaluation of the equivalent number of cycles concept}

The general outline of the numerical method implemented to assess the simplified liquefaction procedure, focussing on the equivalent number of uniform amplitude cycles concept, consists of two types of FE site response analyses of a $15 \mathrm{~m}$ deep level ground fully saturated Nevada sand deposit, as well as single element simple shear test simulations with initial conditions those at $7 \mathrm{~m}$ depth in the deposit:

1. The first type of site response analysis uses full hydro-mechanical coupling to assess the depth of the liquefaction zone. This is used as benchmark in terms of triggering of liquefaction and is compared against the predictions of the empirical assessment (Idriss and Boulanger, 2008).

2. The second type of site response analysis assumes drained conditions to obtain the shear stress time history at mid-depth in the deposit. This excludes any effects of excess pore water pressure development and, in agreement with (Youd et al., 2001), it is used for the conversion to an equivalent number of uniform amplitude cycles. The shear stress time-history at middepth is used rather than the acceleration time-history at ground surface, as is usually the case, for increased accuracy in the conversion to $N_{\text {eq }}$.

3. Single element FE simulations of undrained cyclic simple shear tests with initial conditions those at $7 \mathrm{~m}$ depth in the Nevada sand deposit are then carried out. These are subjected to the equivalent number of cycles as obtained from step 2. Based on Seed et al. (1975), the predictions of the single element tests in terms of triggering of liquefaction should agree with that at mid-depth of the $15 \mathrm{~m}$ deep deposit, as predicted by the corresponding benchmark fully-coupled site response FE analysis (step 1 above).

A more detailed description of each stage of the adopted numerical procedure is given in the following subsections.

\section{Strong motion data}

The ground motions chosen as input at the base of the FE model are the east-west (EW) component of the $20^{\text {th }}$ May 1986 Lotung motion, in Taiwan (Elgamal et al., 1995), the EW component of the $20^{\text {th }}$ September 1999 ChiChi motion, in Taiwan (Tsai and Huang, 2000) and the EW component of the $26^{\text {th }}$ July 2003 Kawasaki motion, Japan (Okada et al., 2003). Each ground motion has very different characteristics, representing a shock-type, a transitional type and a vibratory-type motion, respectively. The former exhibits a pronounced peak, while the latter is expected to more closely represent the uniform amplitudes cycles series. All three acceleration time-histories were recorded in downhole arrays and are representative of bedrock motions. Each ground motion was further scaled to two different levels: one strong enough to induce full liquefaction at a depth of $7 \mathrm{~m}$ depth, defined by an excess pore water pressure ratio, $r_{\mathrm{u}}$, greater than $95 \%$, where $r_{u}$ is equal to the excess pore water pressures, $\Delta u$, over the initial mean effective stress, $p^{\prime}{ }_{\mathrm{v} 0}$, and one weaker to induce marginal liquefaction at a depth of $7 \mathrm{~m}$, with a $r_{\mathrm{u}}$ less than $80 \%$. Drained site response analyses undertaking full liquefaction and marginal liquefaction at $7 \mathrm{~m}$ should provide $N_{\text {eq }}$, and the corresponding single element analyses should reflect the same behaviour. Table 1 summarizes the main characteristics for each ground motion, while Figure 1 to Figure 3 show the acceleration time histories and corresponding Fourier spectra for each record.

Table 1: Characteristics of input ground motions

\begin{tabular}{|c|c|c|c|c|c|}
\hline & $\begin{array}{c}\text { Peak } \\
\text { acceleration, } \\
\mathrm{m} / \mathrm{s}^{2}\end{array}$ & Magnitude & Duration, s & $\begin{array}{c}\text { Scaling } \\
\text { factor }\end{array}$ & Type \\
\hline $\begin{array}{c}\text { Lotung, } \\
1986\end{array}$ & 0.81 & $M_{\mathrm{L}}=4.2$ & 36 & $\mathrm{x} 1.5 / \mathrm{x} 2.0$ & Shock \\
\hline $\begin{array}{c}\text { Chi-Chi, } \\
\text { 2003 }\end{array}$ & 0.41 & $M_{\mathrm{w}}=7.3$ & 110 & $\mathrm{x} 1.2 / \mathrm{x} 1.5$ & Transitional \\
\hline $\begin{array}{c}\text { Kawasaki, } \\
1999\end{array}$ & 1.13 & $M_{\mathrm{w}}=5.6$ & 106 & $\mathrm{x} 10 / \mathrm{x} 12$ & Vibratory \\
\hline
\end{tabular}

$M_{\mathrm{w}}:$ moment magnitude $/ M_{\mathrm{L}}$ : Richter local magnitude 
a)

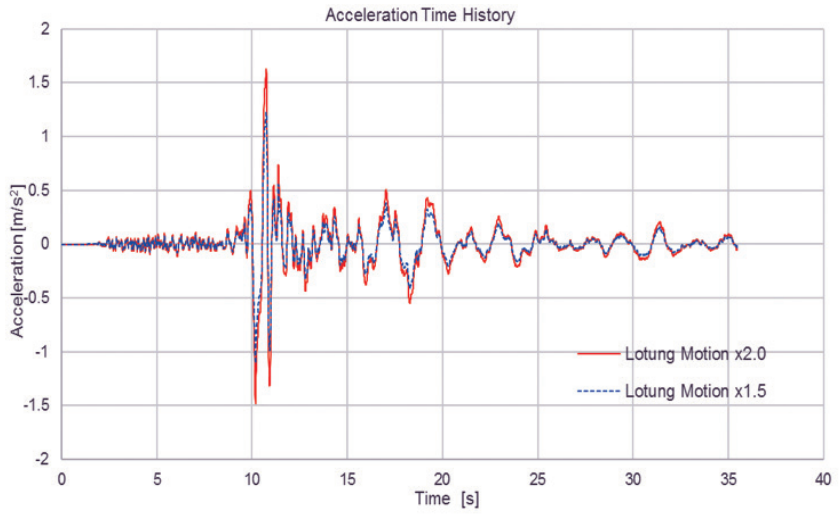

b)

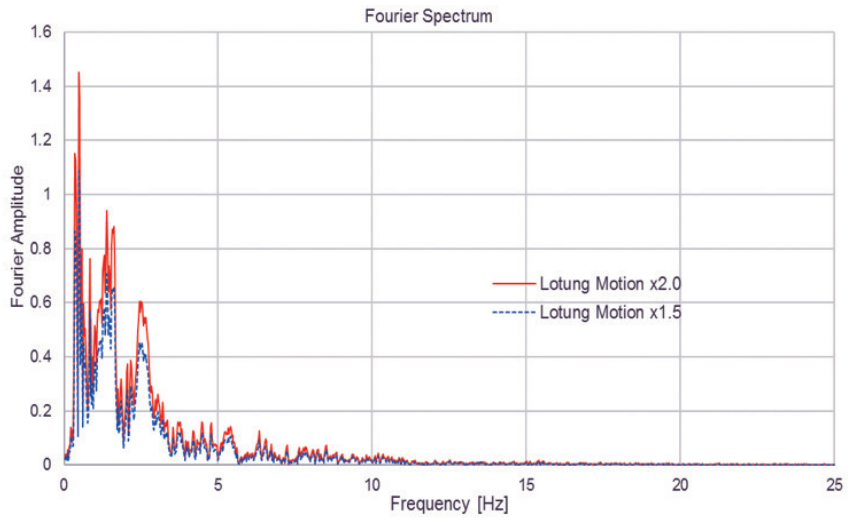

Figure 1: a) Acceleration record and b) Fourier spectrum for Lotung 1986 motion.

a)

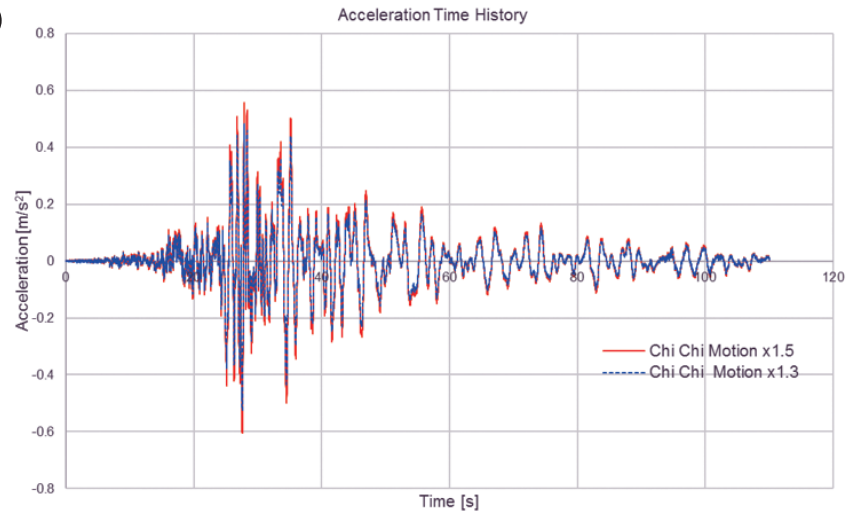

b)

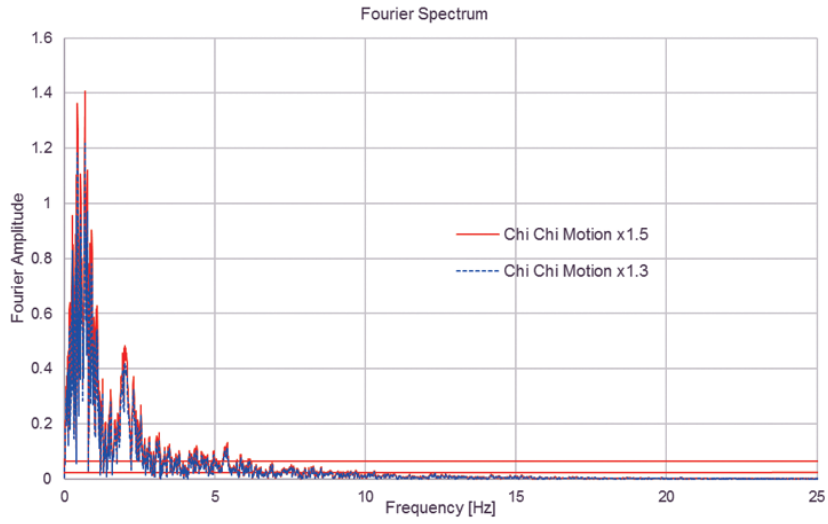

Figure 2: a) Acceleration records and b) Fourier spectrum for Chi-Chi 1999 motion.
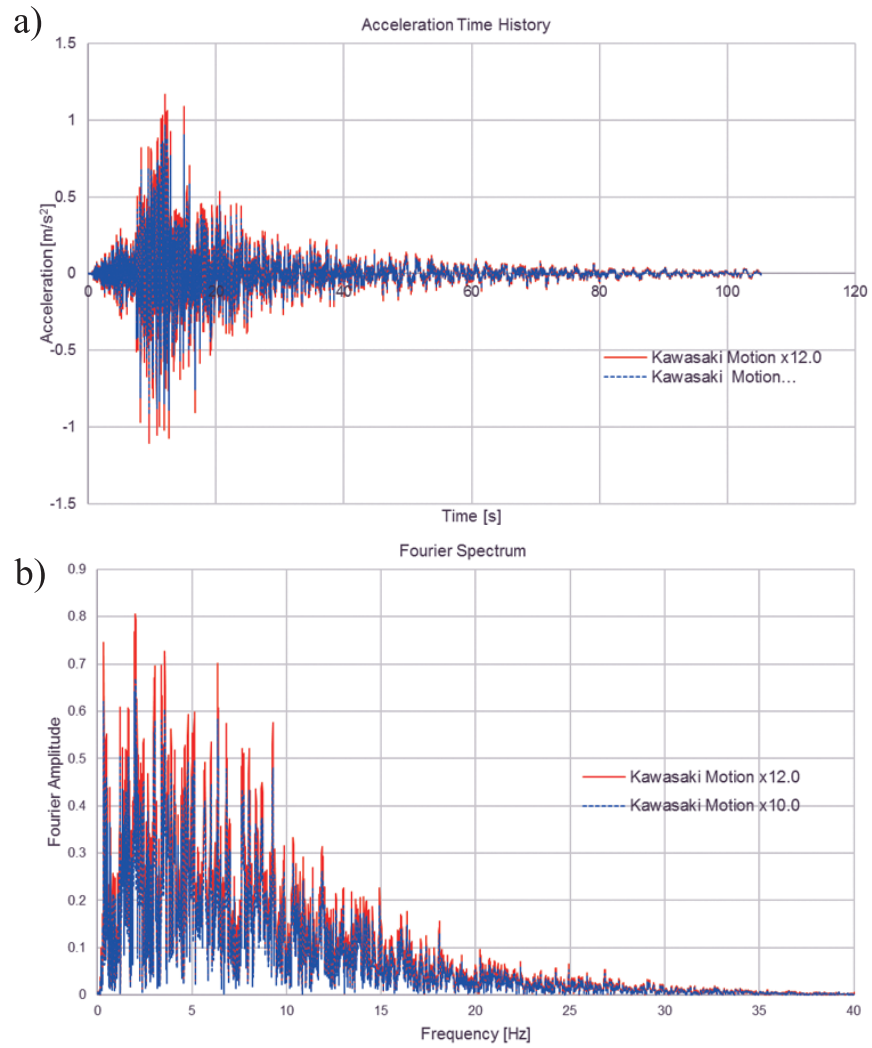

Figure 3: a) Acceleration records and b) Fourier spectrum for Kawasaki 2003 motion.

\section{Methods for counting the number of cycles}

Cycle counting methods are used to count the ranges or peaks of irregular time-histories. The rainflow range counting method (ASTM E1049, 2011) was utilised in this study to count the ranges of the shear stress time-histories, in accordance with the recommendations of Hancock and Bommer (2005). These ranges were then converted into peaks for the calculation of $N_{\text {eq }}$ according to the Seed et al. (1975) procedure.

\section{Equivalent number of cycles}

Earthquake loading patterns are extremely irregular. The representation of earthquake seismic motions as a series of uniform amplitude cycles allows to simplify the conduction of element tests in the laboratory, which are carried out with the aim to investigate the response of soil under seismic conditions.

To convert an irregular time-history to an equivalent number of uniform amplitude cycles, the resulting peaks, as obtained in accordance to the previous section, are used following the process of application of weighting factors of Seed et al. (1975), described in detail in Tsaparli et al. (2015). 


\section{Finite element analyses}

As aforementioned, site response FE analyses simulating a $15 \mathrm{~m}$ deep level ground fully saturated Nevada sand deposit, with a relative density of $40 \%$ are carried out. Two types of site response analyses are performed: the first one is the benchmark case that uses full hydro-mechanical coupling to assess the depth of the liquefaction zone. The second one assumes drained conditions in order to obtain the shear stress time history at mid-depth in the deposit, which is then used for the conversion to an equivalent number of uniform amplitude cycles.

The 3 different input motions, each scaled to two different levels, along with the two types of site response analyses resulted in a total of 12 site response FE analyses. Their characteristics are summarized in Table 2, along with the predictions of the peak ground acceleration (PGA) and the maximum shear stress, $\tau_{\mathrm{xy}}$, registered at $7 \mathrm{~m}$ depth in the drained analyses, as well as the maximum excess pore water pressure ratio, $r_{\mathrm{u}}$, predicted at $7 \mathrm{~m}$ depth in the fully coupled analysis.

Subsequently, single element FE simulations of undrained cyclic simple shear tests with initial conditions those at $7 \mathrm{~m}$ depth in the Nevada sand deposit are carried out, under different confining pressures, representative of the different depths of the soil deposit. These are subjected to the equivalent number of cycles as obtained from the drained site response analyses, under uniform amplitudes at different percentages of the peak shear stress in the timehistory. Based on Seed et al. (1975), the predictions of the single element tests in terms of triggering of liquefaction should agree with those at $7 \mathrm{~m}$ depth in the Nevada sand deposit, as predicted by the corresponding benchmark fully-coupled site response FE analysis. An excess pore water pressure ratio over $95 \%$ was once again used as the criterion to define the occurrence of liquefaction.

The mechanical behaviour of sand is modelled using a bounding surface plasticity model, originally implemented in ICFEP in three-dimensional stress space by Taborda (2011) and Taborda et al. (2014). The modifications to the flow rule and the tensor representing the evolution of soil fabric for accurate prediction of cyclic strength at varying CSRs and overburden effects, as well as better compliance following a dilative response and subsequent unloading, as described in Tsaparli (2017), have also been included. This consists of a significant improvement to Tsaparli et al. (2015), as accurate modelling of cyclic strength is of outmost importance when it comes to the type of study presenting herein. The model requires as input 32-parameters and it was calibrated based on extensive element testing on Nevada sand. More details can be found in Tsaparli (2017).

The mesh generated for the site response analyses, of the $15 \mathrm{~m}$ depth sand deposit, consists on a column of 60 elements stacked up vertically. The type of element to be used corresponds to 8-noded quadrilateral elements with dimensions of $25 \mathrm{~cm}$ per side. The selection of the size of the elements was based on the recommendations of Bathe (1996) for 8 noded elements, in order to ensure that the mesh is fine enough, to avoid the filtering of short wavelength waves.

Table 2: Summary of the site response FE analyses

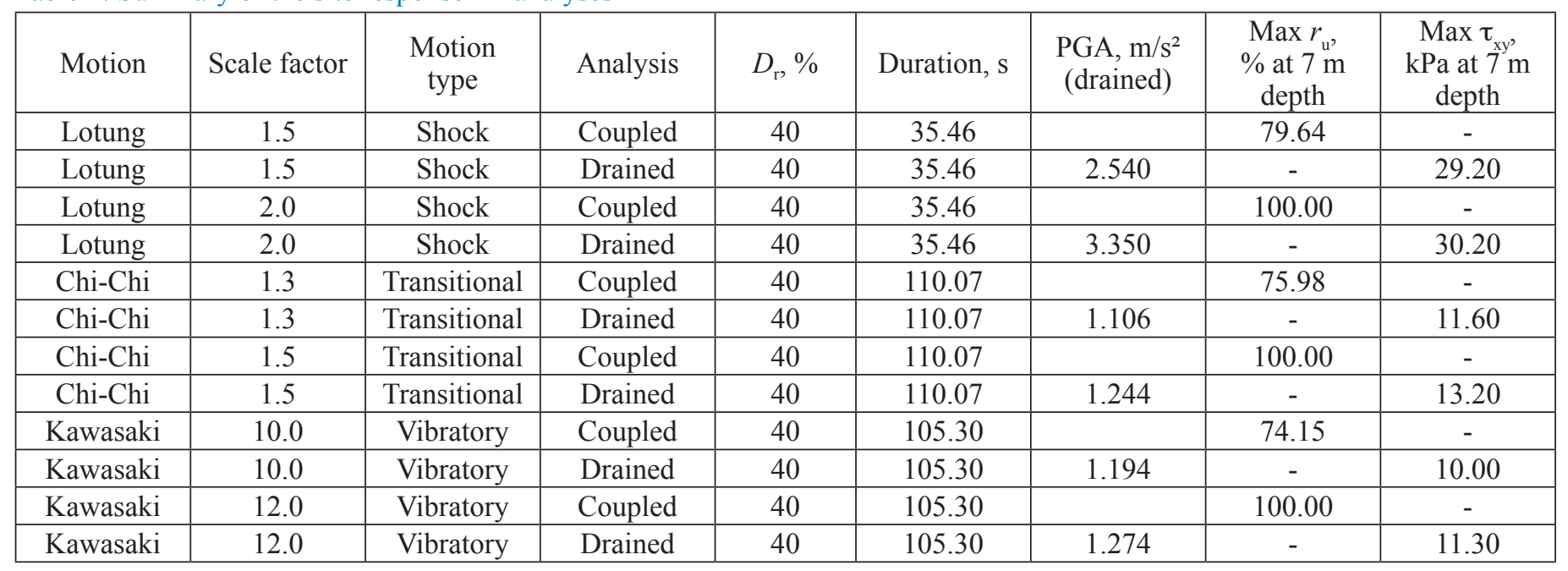


The boundary conditions in the site response analysis consisted in tied degrees of freedom for all node along the vertical boundaries of the mesh to ensure $1 \mathrm{D}$ conditions (Zienkiewicz et al., 1988). The vertical displacement was fixed by restricting vertical movements form the bottom boundary of the mesh. For each motion, the acceleration was transformed into incremental, and it was applied that way at the base of the mesh.

A modified Newton-Raphson integration scheme was used, with a sub-stepping stress point algorithm based on the non-linear solver (Potts and Zdravkovic, 1999). The integration scheme used was the generalized alpha method of Chung and Hulbert (1993) based on a spectral radius of $\rho_{\infty}=0.818$. A time step of $\Delta t=0.01 \mathrm{~s}$ was found to be small enough to achieve an accurate solution for all the motions. This combination would allow to minimize the numerical damping and the period elongation.

\section{Results}

Based on the fully coupled analysis Lotung x1.5 motion was selected to marginally liquefy at a depth of $7 \mathrm{~m}$ with a pore water pressure ratio $r_{\mathrm{u}}$ of $79.64 \%$. Nevertheless, the associated single element (SE) analyses with lower CSR evidenced liquefaction $\left(r_{\mathrm{u}}=95 \%\right)$, while higher CSR did not, as the equivalent number of cycles were not enough to build up pore pressure to trigger liquefaction.

The coupled site response analysis using the Lotung x 2.0 motion presented full liquefaction $\left(r_{\mathrm{u}}=100 \%\right)$ up to a depth of $9 \mathrm{~m}$ approximately. Surprisingly, the SE analyses yield the same results in terms of liquefaction of Lotung x1.5 motion, only lower CSR reached liquefaction. The results for both motions are presented in Table 3 .

The Chi-Chi x1.3 motion was selected to marginally liquefy $\left(r_{\mathrm{u}}=75.98 \%\right)$, the SE analyses presented liquefaction on the lower CSR (higher number of cycles) only, similar to Lotung motions. On Chi-Chi x1.5, all SE analyses had enough cycles to reach the $r_{\mathrm{u}}$ criterion, in conformity to the associated site response analysis that showed full liquefaction $\left(r_{\mathrm{u}}=100 \%\right)$ at the analysed depth. The results for both motions are presented in Table 4 .

Table 3: Lotung motion single element DSS test results for equivalent number of cycles.

\begin{tabular}{|c|c|c|c|c|c|c|c|c|c|}
\hline \multicolumn{4}{|c|}{ Lotung x1.5 motion - Marginal liquefaction } & \multicolumn{4}{c|}{ Lotung x2.0 motion - Full liquefaction } \\
\hline $\begin{array}{c}\% \text { of max. } \\
\tau_{\mathrm{xy}}\end{array}$ & $\begin{array}{c}\text { Max } \tau_{\mathrm{xy}} \\
\mathrm{kPa}\end{array}$ & $\mathrm{CSR}$ & $\begin{array}{c}\text { Equiva- } \\
\text { lent No of } \\
\text { cycles }\end{array}$ & $\begin{array}{c}\text { Cycles to } \\
r_{\mathrm{u}}=95 \%\end{array}$ & $\begin{array}{c}\% \text { of max. } \\
\tau_{\mathrm{xy}}\end{array}$ & $\begin{array}{c}\text { Max } \tau_{\mathrm{xy}} \\
\mathrm{kPa}\end{array}$ & $\begin{array}{c}\text { Equivalent } \\
\text { CSR }\end{array}$ & $\begin{array}{c}\mathrm{N}^{\circ} \text { of } \\
\text { cycles }\end{array}$ & $\begin{array}{c}\text { Cycles to } \\
r_{\mathrm{u}}=95 \%\end{array}$ \\
\hline 0.65 & 19.0 & 0.43 & 1.57 & - & 0.65 & 19.6 & 0.44 & 0.64 & - \\
\hline 0.40 & 11.7 & 0.26 & 41.73 & 2.50 & 0.4 & 12.1 & 0.27 & 16.99 & 2.50 \\
\hline 0.50 & 14.6 & 0.33 & 7.30 & 2.00 & 0.5 & 15.1 & 0.34 & 2.97 & 2.00 \\
\hline 0.70 & 20.4 & 0.46 & 1.25 & - & 0.7 & 21.1 & 0.48 & 0.51 & - \\
\hline 0.80 & 23.4 & 0.53 & 0.91 & - & 0.8 & 24.2 & 0.55 & 0.37 & - \\
\hline 0.90 & 26.3 & 0.59 & 0.65 & - & 0.9 & 27.2 & 0.61 & 0.27 & - \\
\hline 1.00 & 29.2 & 0.66 & 0.52 & - & 1 & 30.2 & 0.68 & 0.21 & - \\
\hline
\end{tabular}

Table 4: Chi-Chi motion single element DSS test results for equivalent number of cycles.

\begin{tabular}{|c|c|c|c|c|c|c|c|c|c|}
\hline \multicolumn{4}{|c|}{ Chi Chi x1.3 motion - Marginal liquefaction } & \multicolumn{5}{c|}{ Chi Chi x1.5 motion - Full liquefaction } \\
\hline $\begin{array}{c}\text { \% of max. } \\
\tau_{\mathrm{xy}}\end{array}$ & $\begin{array}{c}\text { Max } \tau_{\mathrm{xy}} \\
\mathrm{kPa}\end{array}$ & CSR & $\begin{array}{c}\text { Equiva- } \\
\text { lent N } \mathrm{N}^{\mathrm{o}} \\
\mathrm{cycles}\end{array}$ & $\begin{array}{c}\text { Cycles to } \\
r_{\mathrm{u}}=95 \%\end{array}$ & $\begin{array}{c}\% \text { of max. } \\
\tau_{\mathrm{xy}}\end{array}$ & $\begin{array}{c}\text { Max } \tau_{\mathrm{xy}} \\
\mathrm{kPa}\end{array}$ & CSR & $\begin{array}{c}\text { Equivalent } \\
\mathrm{N}^{\circ} \text { of } \\
\text { cycles }\end{array}$ & $\begin{array}{c}\text { Cycles to } \\
r_{\mathrm{u}}=95 \%\end{array}$ \\
\hline 0.65 & 7.5 & 0.17 & 5.70 & 5.50 & 0.65 & 8.6 & 0.19 & 6.00 & 4.00 \\
\hline 0.40 & 4.6 & 0.10 & 151.97 & 14.50 & 0.4 & 5.3 & 0.12 & 159.95 & 10.55 \\
\hline 0.50 & 5.8 & 0.13 & 26.60 & 9.00 & 0.5 & 6.6 & 0.15 & 27.99 & 7.00 \\
\hline 0.70 & 8.1 & 0.18 & 4.56 & 4.50 & 0.7 & 9.2 & 0.21 & 4.80 & 3.50 \\
\hline 0.80 & 9.3 & 0.21 & 3.32 & - & 0.8 & 10.6 & 0.24 & 3.50 & 3.00 \\
\hline 0.90 & 10.4 & 0.24 & 2.37 & - & 0.9 & 11.9 & 0.27 & 2.50 & 2.50 \\
\hline 1.00 & 11.6 & 0.26 & 1.90 & - & 1 & 13.2 & 0.30 & 2.00 & 2.00 \\
\hline
\end{tabular}


Table 5: Kawasaki motion single element DSS test results for equivalent number of cycles.

\begin{tabular}{|c|c|c|c|c|c|c|c|c|c|}
\hline \multicolumn{4}{|c|}{ Kawasaki x10.0 motion - Maginal liquefaction } & \multicolumn{4}{c|}{ Kawasaki x12.0 motion - Full liquefaction } \\
\hline $\begin{array}{c}\text { \% of max. } \\
\tau_{\mathrm{xy}}\end{array}$ & $\begin{array}{c}\text { Max } \tau_{\mathrm{xy}} \\
\mathrm{kPa}\end{array}$ & CSR & $\begin{array}{c}\text { Equiva- } \\
\text { lent } \mathrm{N}^{\circ} \text { of } \\
\text { cycles }\end{array}$ & $\begin{array}{c}\text { Cycles to } \\
r_{\mathrm{u}}=95 \%\end{array}$ & $\begin{array}{c}\text { \% of max. } \\
\tau_{\mathrm{xy}}\end{array}$ & $\begin{array}{c}\text { Max } \tau_{\mathrm{xy}} \\
\mathrm{kPa}\end{array}$ & CSR & $\begin{array}{c}\text { Equivalent } \\
\mathrm{N}^{\circ} \text { of } \\
\text { cycles }\end{array}$ & $\begin{array}{c}\text { Cycles to } \\
r_{\mathrm{u}}=95 \%\end{array}$ \\
\hline 0.65 & 6.5 & 0.15 & 18.08 & 7.00 & 0.65 & 7.5 & 0.17 & 16.77 & 5.50 \\
\hline 0.40 & 4.0 & 0.09 & 482.13 & 23.00 & 0.4 & 4.6 & 0.10 & 447.07 & 14.50 \\
\hline 0.50 & 5.0 & 0.11 & 84.37 & 12.00 & 0.5 & 5.8 & 0.13 & 78.24 & 9.00 \\
\hline 0.70 & 7.0 & 0.16 & 14.46 & 6.00 & 0.7 & 8.1 & 0.18 & 13.41 & 4.50 \\
\hline 0.80 & 8.0 & 0.18 & 10.55 & 5.00 & 0.8 & 9.3 & 0.21 & 9.78 & 3.50 \\
\hline 0.90 & 9.0 & 0.20 & 7.53 & 4.00 & 0.9 & 10.4 & 0.24 & 6.99 & 3.00 \\
\hline 1.00 & 10.0 & 0.22 & 6.03 & 3.00 & 1 & 11.6 & 0.26 & 5.59 & 2.50 \\
\hline
\end{tabular}

Finally, the Kawasaki motion, the most vibratory of the three studied records, both $\times 10.0$ and x12.0 scaling factors, exhibited liquefaction in all SE analyses. In general, results are very conservative, but not accurate, particularly for Kawasaki x10.0 motion. The results of Kawasaki motions that marginally and fully liquefy are presented in Table 5.

In parallel, the results of the fully coupled benchmark analyses at $7 \mathrm{~m}$ depth were checked against the predictions of the empirical simplified procedure (Idriss and Boulanger, 2008). The results obtained in the simplified procedure are similar to the SE analyses. Similarly, non-conservative results have been found for shock type motions.

\section{Conclusions}

The Seed et al. methdology and Miner's concept of cumulative damage for soils has been studied numerically through a benchmark study. The first impression of the single element DSS simulations results was that for the same motion, the equivalent number of cycles at different stress levels by Seed et al. (1975) methodology, the response was quite different. This observation was particularly accentuated for the Lotung shock type motions, associated with a reduced number of cycles.

Previous research (Biondi et al., 2004), observed the equivalent cycles methodologies do not comply good enough for very low CSR, while for high CSR, has been proved how conservative is showing that is not critical. This observation does not agree with what was observed particularly on the shock type motion.

In general, the simplified procedure presents very conservative results to the benchmark site response analyses, but in agreement with the SE analyses, for the analysed shock type motion safety factors over 1.0, were obtained on motions that exhibited full liquefaction on the coupled site response analyses.

In a liquefaction point of view, the Seed et al. (1975) methodology has evidenced to be motion dependant. Shock type motions have evidenced non-conservative results while for vibratory type motions the findings are the opposite, very conservative.

Future research should include a detailed study on the performance of the bounding surface plasticity model on boundary value problems using high density on material properties. This would require an extensive advanced laboratory testing using high relative densities.

Further work should be carried out, considering new energy-based approaches instead of equivalent number of cycles, to perform liquefaction assessments. A recent investigation has shown better and more accurate methods to capture the irregular effects of seismic loading (Pan and Yang, 2019), instead of the early presented equivalent methodology (Seed et al., 1975).

\section{References}

ASTM E1049 (2011). Standard practices for cycle counting definitions for fatigue analysis. ASTM International, West Conshohocken, PA, USA

Azeiteiro, R.N.J., Marques, V.D. and Coelho, P.A.L.F (2012). Effect of singular peaks in uniform cyclic loading on the liquefaction resistance of a sand. $2^{\text {nd }}$ International Conference on Performance-Based Design in Earthquake Geotechnical Engineering, Taormina, Italy

Bathe, K. (1996). Finite element procedures. New Jersey: Prentince Hall 
Biondi, G., Cascone, E. and Maugeri, M. (2004). Number of uniform stress cycles equivalent to seismic loading. $11^{\text {th }}$ International Conference on Soil Dynamics and Earthquake Engineering and $3^{\text {rd }}$ International Conference on Earthquake Geotechnical Engineering, vol. 2, Berkeley, California, USA, 705-712

Chung, J. and Hulbert, G.M. (1993). A time integration algorithm for structural dynamics with improved numerical dissipation: The generalized- $\alpha$ method. Journal of Applied Mechanics 60(2), 371-375

Coelho, P.A.L.F., Azeiteiro, R.J.N., Marques, V.D., Santos, L.M.A. and Taborda, D.M.G. (2013). Challenges to the laboratory evaluation of field liquefaction resistance. $18^{\text {th }}$ International Conference on Soil Mechanics and Geotechnical Engineering, Paris, France, 1459-1462

Elgamal, A.-W., Zeghal, M., Tang, H.T. and Stepp, J.C. (1995). Lotung downhole array. I: Evaluation of site dynamic properties. Journal of Geotechnical Engineering 121(4), 350-362

Hancock, J. and Bommer, J. (2005). The effective number of cycles of earthquake ground motions. Earthquake Engineering and Structural Dynamics 34, 637-664

Hazen, A. (1920). Hydraulic-fill dams. Transactions of the American Society of Civil Engineers 83(1), 1713-1745

Idriss, I. and Boulanger, R. (2008). Soil liquefaction during earthquakes. Oakland, California: Earthquake Engineering Research Institute

Miner, M. (1945). Cummulative damage in failure. Journal of Applied Mechanics 12(3), 159-164

Okada, T., Umino, N. and Hasegawa, A. (2003). Rupture process of the July 2003 northern Miyagi earthquake sequence, NE Japan, estimated from double-difference hypocenter locations. Earth, Planets and Space 55(12), 741-750

Pan, K. and Yang. Z.X. (2019). Evaluation of the liquefaction potential of sand under random loading conditions: equivalent approach versus energy-based method. Journal of Earthquake Engineering (in press)

Papadimitiou, A.G. and Bouckovalas, G.D. (2002). Pasticity model for sand under small and large cyclic strains; a multiaxial formulation. Soil Dynamics and Earthquake Engineering 127(11), 191-204
Potts, D.M. and Zdravkovic, L. (1999). Finite element analysis in geotechnical engineering: theory. Thomas Telford, London, UK

Seed, H.B. and Idriss, I.M. (1971). Simplified procedure for evaluating soil liquefaction potential. Journal of Soil Mechanics and Foundation Division 97(9), 1249-1273

Seed, H.B., Idriss, I.M., Makdisi, F. and Banerjee, N. (1975). Representation of irregular stress time histories by equivalent uniform stress series in liquefaction analysis. Earthquake Engineering Research Center, Berkeley, California

Shen, C.K., Harder, A.M., Vrymoed, J.L. and Bennett, W.J. (1978). Dynamic response of a sand under random loadings. ASCE Geotechnical Engineering Division Special Conference on Earthquake Engineering and Soil Dynamics, vol. 2, 852-863

Taborda, D.M.G. (2011). Development of constitutive models for application in soil dynamics. $\mathrm{PhD}$ thesis, Imperial College London, UK

Taborda, D., Zdravkovic, L., Kontoe, S. and Potts, D. (2014). Computational study on the modification of a bounding surface plasticity model for sands. Computers and Geotechnics 59, 145160

Tsai, Y.-B. and Huang, M.-W. (2000). Strong ground motion characteristics of the Chi-Chi, Taiwan, earthquake of September 21, 1999. Earthquake Engineering \& Engineering Seismology 2(1), 1-21

Tsaparli. V. (2017). Numerical modelling of earthquake-induced liquefaction under irregular and multi-directional loading. $\mathrm{PhD}$ thesis, Imperial College London, UK

Tsaparli, V., Kontoe, S., Taborda, D.M.G. and Potts, D.M. (2015). Numerical investigation of the effect of the irregular nature of the seismic loading on the liquefaction resistance of saturated sand deposits. Society for Earthquake and Civil Engineering Dynamics SECED 2015 Conference: Earthquake Risk and Engineering towards a Resilient World, Cambridge, UK

Tsuchida, H. (1970). Prediction and counter measure against the liquefaction in sand deposits. Abstracts of Seminars in the Ports and Harbour Research Institute, Japan, 3.1-3.33 (in Japanese)

Youd, T.L. and Perkins, D.M. (1978). Mapping liquefactioninduced ground failure potential. Journal of the Geotechnical Engineering Division 104(4), 433-446 
Youd, T.L., Idriss, I.M., Andrus, R.D., Arango, I., Castro, G., Zienkiewicz, O., Bicanic, N. and Shen, F.Q. (1988). Earthquake Christian, J.T., Dobry, R., Finn, W.D.L., Harder, L.F., Hynes, input definition and the transmitting boundary conditions. In M.E., Ishihara, K., Koester, J.P., Liao, S.S.C., Marcuson III, Advances in Computational Nonlinear Mechanics, I.S. Doltnis W. F., Martin, G.R., Mitchell, J.K., Moriwaki, Y., Power, M. (ed.), 109-138, Springer S., Robertson, P. K., Seed, R.B. and Stokoe II, K.H. (2001). Liquefaction resistance of soils: summary report from the 1996 NCEER and 1998 NCEER/NSF Workshops. Journal of Geotechnical and Geoenvironmental Engineering 127(10), 817833 